\title{
Efek Nigella Sativa Terhadap LDL Teroksidasi pada Tikus Hiperkolesterolemia
}

Martha Ardiaria

\section{Bagian Gizi, Fakultas Kedokteran, Universitas Diponegoro}

\begin{abstract}
ABSTRAK
Latar Belakang: Asupan antioksidan dipercaya dapat memperbaiki penyakit degeneratif yang dipicu oleh keadaan stress metabolik. Nigella sativa(NS) sebagai salah satu herbal yang terbukti memiliki aktivitas antioksidan memilik potensi mencegah atau mengurangi oksidasi LDL sehingga lebih lanjut diduga dapat mengurangi peluang terjadinya aterosklerosis sekaligus kejadian PJK dan penyakit lain yang dilatarbelakangi oleh proses stres metabolik.
\end{abstract}

Metode: Darah diambil dari pleksus orbita sebanyak $3 \mathrm{~mL}$ kemudian dilakukan sentrifugasi untuk mendapatkan plasma. Kadar oxLDL diukur menggunakan metode ELISA. Angka optical density (OD) yang dihasilkan oleh ELISA reader diplotkan ke dalam kurva standard untuk mendapatkan kadar oxLDL. Kadar HDL diukur menggunakan metode presipitasi kuantitatif.

Hasil: Tidak ada perbedaan yang signifikan secara statistik namun kadar LDL terendah berada pada kelompok perlakuan 2. Begitu pula dengan kadar oxLDL, hasil terendah berada pada kelompok 3 walaupun tidak terdapat perbedaan yang signifikan.

Kata Kunci: LDL,Nigella sativa, aterosklerosis 


\section{PENDAHULUAN}

Low density lipoprotein (LDL) teroksidasi atau oxLDL, didefinisikan sebagai partikel berasal dari LDL yang memiliki peroksida maupun produk degradasi lainnya, di dalam molekul LDL itu sendiri atau di bagian lain dari tubuh yang terkait dengan proses tersebut. ${ }^{1}$ Oksidasi LDL terjadi karena adanya spesies radikal bebas di tubuh yang diperoleh dari berbagai sumber, salah satunya adalah pola makan tinggi lemak. ${ }^{1,2}$ Berbagai modifikasi yang terjadi pada oxLDL membuatnya memiliki tingkat aterogenisitas yang lebih tinggi dibandingkan LDL yang tidak teroksidasi dan merupakan faktor kunci terjadinya berbagai penyakit degeneratif.,

Peningkatan kejadian penyakit degeneratif dan semakin dini onset terjadinya penyakit tersebut baik di negara maju maupun berkembang menimbulkan keprihatinan tersendiri bagi dunia kedokteran. Diperkirakan puluhan juta orang meninggal lebih dini setiap tahunnya karena penyakit degeneratif. ${ }^{4}$ Gaya hidup sedenter dikombinasikan dengan diet tinggi lemak dianggap terkait erat dengan fenomena tersebut.Pola makan tinggi lemak, khususnya asam lemak jenuh dan trans, terbukti terkait erat dengan dislipidemia yang akan menjadi dasar terjadinya berbagai penyakit degeneratif. ${ }^{3-7}$

Asupan antioksidan dipercaya dapat memperbaiki penyakit degeneratif yang dipicu oleh keadaan stress metabolik. Nigella sativa(NS) sebagai salah satu herbal yang terbukti memiliki aktivitas antioksidan memilik potensi mencegah atau mengurangi oksidasi LDL sehingga lebih lanjut diduga dapat mengurangi peluang terjadinya aterosklerosis sekaligus kejadian PJK dan penyakit lain yang dilatarbelakangi oleh proses stres metabolik. ${ }^{8}$

\section{METODE}

\section{Subjek}

Tikus Sprague Dawley jantan sebanyak 18 ekor dipilih secara acak untuk dibagi menjadi 3 kelompok, yaitu 1 kelompok kontrol dan 3 kelompok perlakuan. Semua tikus mendapatkan diet tinggi lemak trans $10 \%$ total kalori/hari dengan kelompok perlakuan 1, 2, dan 3 masing diberikan ekstrak NS sebesar 125, 250, dan $500 \mathrm{mg} / \mathrm{kgBB}$ selama 4 minggu. Parameter yang diukur pada akhir penelitian adalah kadar HDL, LDL, dan oxLDL.

\section{Ekstraksi NS}

Biji NS dibeli dari PT. Jamu Borobudur kemudian dilakukan ekstraksi menggunakan pelarut etanol $70 \%$ dengan metode perkolasi. 


\section{Spesimen}

Darah diambil dari pleksus orbita sebanyak $3 \mathrm{~mL}$ kemudian dilakukan sentrifugasi untuk mendapatkan plasma. Kadar oxLDL diukur menggunakan metode ELISA. Angka optical density (OD) yang dihasilkan oleh ELISA reader diplotkan ke dalam kurva standard untuk mendapatkan kadar oxLDL. Kadar HDL diukur menggunakan metode presipitasi kuantitatif.

\section{ANALISIS STATISTIK}

Data yang didapat diolah menggunakan perangkat lunak SPSS versi 16. Statistik deskriptif digunakan untuk mendapatkan nilai rerata \pm SD untuk semua variabel. Perbedaan kadar oxLDL antarpada tiap kelompok diuji menggunakan uji beda ANOVA. Perbedaan dianggap signifikan apabila nilai $\mathrm{p}<0.05$.

\section{Isu Etik}

Penelitian ini dilakukan setelah diterbitkannya Ethical Clearance dari Universitas Gajah Mada di Yogyakarta.

\section{HASIL}

Tabel 1. Kadar HDL, LDL, dan oxLDL pada Tikus Setelah Diberi Perlakuan

\begin{tabular}{cccccc}
\hline Variabel & Kontrol & $\mathrm{K} 1$ & $\mathrm{~K} 2$ & $\mathrm{~K} 3$ & $p$ \\
& $\mathrm{x} \pm \mathrm{SD}$ & $\mathrm{x} \pm \mathrm{SD}$ & $\mathrm{x} \pm \mathrm{SD}$ & $\mathrm{x} \pm \mathrm{SD}$ & value \\
\hline Kadar HDL $(\mathrm{mg} / \mathrm{dl})$ & $30.73 \pm$ & $30.10 \pm$ & $23.83 \pm$ & $26.48 \pm$ & 0.077 \\
& 7.357 & 4.280 & 3.547 & 3.142 & \\
Kadar LDL $(\mathrm{mg} / \mathrm{dl})$ & $19.67 \pm$ & $23.42 \pm$ & 16.42 & $20.43 \pm$ & 0.075 \\
& 5.814 & 3.866 & \pm 4.523 & 2.268 & \\
Kadar oxLDL $(\mathrm{mg} / \mathrm{dl})$ & $157.32 \pm$ & $141.18 \pm$ & $148.62 \pm$ & $136.94 \pm$ & 0.069 \\
& 24.436 & 24.057 & 22.454 & 25.762 & \\
\hline
\end{tabular}

Tidak ada perbedaan yang signifikan secara statistik namun kadar LDL terendah berada pada kelompok perlakuan 2. Begitu pula dengan kadar oxLDL, hasil terendah berada pada kelompok 3 walaupun tidak terdapat perbedaan yang signifikan.

\section{DISKUSI}

\section{Kapasitas antioksidan pada NS}

Banyak penelitian menunjukkan bahwa oksidasi LDL dapat dihambat menggunakan antioksidan tertentu yang terdapat secara alami dalam tubuh maupun terkadung dalam tanaman. ${ }^{9-11}$ Penelitian menggunakan NS untuk menghambat oksidasi LDL telah dilakukan secara in vitro. Kapasitas antioksidan NS telah dibuktikan terkait dengan kapasitasnya membuang DPPH dan radikal 
bebas yang dihasilkan oleh DPPH. Nigella sativamemiliki kapasitas antioksidan yang sebanding dengan vitamin E. ${ }^{9-12}$

Olahan biji NS diketahui memiliki aktivitas antioksidan yang kuat. Salah satu kandungan NS Kandungan antioksidan utama pada NS adalah thymoquinon (TQ) yang terbukti memiliki efek protektif terhadap kerusakan oksidatif dengan cara menjadi scavenger berbagai macam spesies radikal. ${ }^{9-12}$

Tikus pada penelitian ini diberi pakan tinggi lemak trans untuk memicu terjadinya peningkatan kadar LDL dan stress oksidatif. Penurunan oxLDL paling rendah terdapat pada kelompok 3 dengan dosis NS tertinggi. Kemampuan scavenging spesies radikal sebanding dengan banyaknya kandungan fenol pada ekstrak NS. ${ }^{8,9-11}$

\section{DAFTAR PUSTAKA}

1. Parthasarathy S, Raghavamenon A, Garelnabi MO, Santanam N. Oxidized Low-Density Lipoprotein. In: Uppu RM, Murthy SN, Pryor WA, Parinandi NL. Free radicals and antioxidant protocols. 2nd ed. New York. Humana Press; 2010. P. 403-18.

2. Leopold JA, Loscalzo J. Oxidative risk for atherothrombotic cardiovascular disease. Free Radical Biology \& Medicine. 2009;47:1673- 1706.

3. Meydani M, Eun HK, Knight A. LDL oxidation as a biomarker of antioxidant status. In: Aldini G, Kyung-Jin Y, Niki N, Russel RM, eds. Biomarkers for antioxidant defense and oxidative damage: principles and practical applications. Iowa: Blackwell Publishing; 2010. P. 51-63.

4. Handajani A, Roosihermiatie B, Maryani H. Faktor-faktor yang berhubungan dengan pola kematian pada penyakit degeneratif di Indonesia. Buletin Penelitian Sistem Kesehatan. 2010;13(1):42-53.

5. Silverstein RL. Inflammation, atherosclerosis, and arterial thrombosis: Role of the scavenger receptor CD36. Cleve. Clin. J.Med. 2009;76 (Suppl 2):S27S30.

6. Sartika RAD. Pengaruh Asupan Asam Lemak Trans terhadap Profil Lipid Darah (Disertasi). Program Doktor Ilmu Epidemiologi Program Pasca Sarjana Fakultas Kesehatan Masyarakat Universitas Indonesia.2007.

7. Putri S, Isnawati M. Hubungan antara asupan asam lemak trans dengan profi lipid pada remaja di SMAN 5 Semarang (Skripsi). Program Studi Ilmu Gizi Fakultas Kedokteran Universitas Diponegoro. 2010.

8. Dhibi M, Brahmi F, Mnari A, Houas Z, Cchargui I, Bchir L, et al. The intake of high fat diet with different trans fatty acid levels differentially induces oxidative stres and non alcoholic fatty liver disease (NAFLD) in rats. Nutrition and Metabolism.2011;8:65. 
9. Lutterodt H, Luther M, Slavin M, Jun JY, Parry J, Jin MG, Yu L. Fatty acid profile, thymoquinone content, oxidative stability, and antioxidant properties of cold-pressed black cumin seed oils. Food Science and Technology.2010;43:1409-1413.

10. Mariod AA, Ibrahim RM, Ismail M, Ismail N. Antioxidant activity and phenolic content of phenolic rich fractions obtained from black cumin (Nigella sativa) seedcake Food Chemistry.2009;116:306-312.

11.Ismail M, Al-Naqeeb G, Chan KW. Nigella sativa thymoquinone-rich fraction greatly improves plasma antioxidant capacity and expression of antioxidant genes in hypercholesterolemic rats. Free Radical Biology \& Medicine.2010;48:664-672.

12.Khoddami A, Ghazali HM, Yassoralipour A, Ramakrishnan Y, Ganjloo A. Physicochemical Characteristics of Nigella Seed (Nigella sativa L.) Oil as Affected by Different Extraction Methods. J Am Oil Chem Soc.2010;88(4):533-540. 